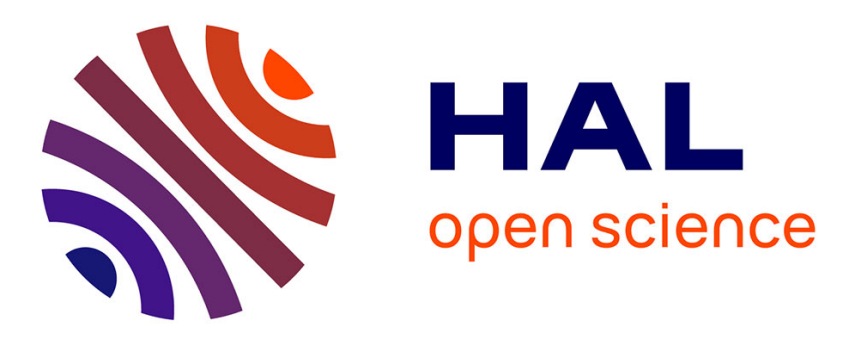

\title{
Optimization of 3-d SAR distribution in local RF hyperthermia
}

Nicolas Siauve, Laurent Nicolas, Christian Vollaire, Alain Nicolas, Joao

Antonio Vasconcelos

\section{- To cite this version:}

Nicolas Siauve, Laurent Nicolas, Christian Vollaire, Alain Nicolas, Joao Antonio Vasconcelos. Optimization of 3-d SAR distribution in local RF hyperthermia. IEEE Transactions on Magnetics, 2004, 40 (2), pp.1264-1267. 10.1109/TMAG.2004.825432 . hal-00140438

\section{HAL Id: hal-00140438 \\ https://hal.science/hal-00140438}

Submitted on 6 Apr 2007

HAL is a multi-disciplinary open access archive for the deposit and dissemination of scientific research documents, whether they are published or not. The documents may come from teaching and research institutions in France or abroad, or from public or private research centers.
L'archive ouverte pluridisciplinaire HAL, est destinée au dépôt et à la diffusion de documents scientifiques de niveau recherche, publiés ou non, émanant des établissements d'enseignement et de recherche français ou étrangers, des laboratoires publics ou privés. 


\title{
Optimization of 3-D SAR Distribution in Local RF Hyperthermia
}

\author{
Nicolas Siauve, Laurent Nicolas, Christian Vollaire, Alain Nicolas, and Joao A. Vasconcelos
}

\begin{abstract}
A procedure to optimize the specific absorption rate deposed in the patient during oncology hyperthermia treatment is presented. It is based on a genetic algorithm coupled to a finiteelement formulation. The optimization procedure is applied to a real human body obtained from computerized tomography scans.
\end{abstract}

Index Terms-Electromagnetic fields, finite-element methods, genetic algorithms, hyperthermia.

\section{INTRODUCTION}

H YPERTHERMIA is used in oncology treatment to treat localized cancerous tumors [1]. The aim of local hyperthermia therapy is to increase the tumor temperature to a range of $42{ }^{\circ} \mathrm{C}-45^{\circ} \mathrm{C}$, while keeping the temperatures in healthy tissues at acceptable levels. The temperature elevation of the tumoral volume increase the effectiveness of conventional treatments such as chemotherapy or radiotherapy [2]. This elevation of temperature is obtained by locally submitting the patient to a radio frequency (RF) or microwave electromagnetic field. Rigorously, the calculation of the temperature distribution in the patient during electromagnetic hyperthermia treatment should be performed from the computation of the specific absorption rate (SAR). However, it has been shown that, in a first approximation, the temperature distribution may be directly related to the SAR distribution [3]. The power deposited by an electric field $E$ in a tissue is given by

$$
\mathrm{SAR}=\frac{1}{2} \frac{\sigma|\mathrm{E}|^{2}}{\rho}
$$

where $|\mathrm{E}|$ is the magnitude of the electric field, $\sigma$ the electrical conductivity $(\mathrm{S} / \mathrm{m})$, and $\rho$ the mass density $\left(\mathrm{kg} / \mathrm{m}^{3}\right)$ of the tissue.

The success of hyperthermia treatment lies in the focalization of the heat inside the cancerous tumor. It is obtained by using several RF sources having specific phases and amplitudes. In this paper, a tool to optimize the SAR distribution in the patient including the specification of constraints is presented. A detailed description of the optimization procedure is first given. Two configurations including the hyperthermia device and a patient are then described. Finally, the optimization procedure is used on these two configurations.

Manuscript received July 1, 2003.

N. Siauve, L. Nicolas, C. Vollaire, and A. Nicolas are with the CEGELY, UMR CNRS, 69131 Ecully cedex, France (e-mail: Laurent.Nicolas@eclyon.fr).

J. A. Vasconcelos is with the Universitade Federale de Minas Gerais, Belo Horizonte, Brazil.

Digital Object Identifier 10.1109/TMAG.2004.825432

\section{OPTIMIZATION}

Energy deposited into the part of the body to be heated is accompanied by energy deposition into other regions. It is impossible to predict intuitively phases and amplitudes of the sources leading to the best focalization. The electric field results from a superposition of $n$ fields generated by $n$ antennas, which can be controlled separately in amplitude and phase. Optimization of these $2 n$ parameters is consequently required. A genetic algorithm (GA) is then used to optimize the SAR distribution [4]. GA follows the principles of evolution through natural selection to maximize a defined objective function $(\mathrm{OF})$.

\section{A. Electric Field Calculation}

To compute the electric field and the SAR distributions, a three-dimensional (3-D) finite element (FE) formulation has been previously developed [5]. The time harmonic formulation is directly written in terms of total electric field $\mathbf{E}$ (2). It is obtained by applying the Galerkin method to the wave equation. Coupling to a first-order Engquist-Majda absorbing boundary condition (ABC) allows us to take into account the open boundary

$$
\begin{aligned}
-\int_{\mathrm{v}} \nabla \mathrm{W} & \times \nabla \times \mathbf{E} \cdot \mathrm{dv}-\int_{\mathrm{v}} \mathrm{Wk}_{0}^{2} \varepsilon_{\mathrm{c}} \mathbf{E} \cdot \mathrm{dv} \\
& +\int_{\mathrm{s}_{\mathrm{ext}}} \mathrm{Wg}_{\mathrm{ABC}}(\mathbf{E}) \cdot \mathrm{ds}=-\mathrm{j} \omega \mu_{0} \int_{\Gamma} \mathrm{WJ} \mathbf{J}_{\mathrm{e}} \cdot \mathrm{dv}
\end{aligned}
$$

with $g_{\mathrm{ABC}}(\mathbf{E})=j k_{0} \mathbf{E}_{t}$, where $\mathbf{E}_{\mathrm{t}}$ is the tangential field.

Space discretization is performed using incomplete first-order edge elements. Edge elements ensure the continuity of the tangential field components across an interface between different media [6]. Tetrahedral elements are used since they fit on complex geometries such as human tissues or hyperthermia applicators. The resulting sparse complex symmetric matrix equation is solved using conjugate gradient solver with potential projection preconditioning [7].

The formulation has been validated by comparison to calculated SAR distribution on a phantom to temperature measurements [5].

\section{B. Optimization Procedure}

The hyperthermia system consists of $n$ applicators, each of them contributing to a part of the total $\mathbf{E}$ field. The $\mathbf{E}$ field distribution due to each source is first computed with the FE method, 
TABLE I

DEFINITION OF THE OBJeCTIVE FunCtIONS

\begin{tabular}{|c|c|}
\hline 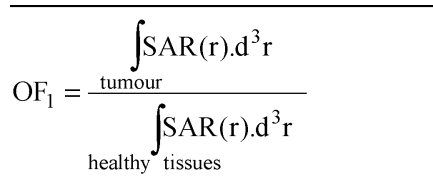 & $\mathrm{OF}_{2}=\frac{\int \operatorname{SAR}(\mathrm{r}) \cdot \mathrm{d}^{3} \mathrm{r}}{\int_{\text {tumour }} \operatorname{SAR}(\mathrm{r}) \cdot \mathrm{d}^{3} \mathrm{r}+\int_{\text {healthy }} \alpha(\mathrm{r}) \operatorname{SAs} \mathrm{SAR}(\mathrm{r}) \cdot \mathrm{d}^{3} \mathrm{r}}$ \\
\hline $\mathrm{OF}_{3}=\frac{\int \mathrm{SAR}(\mathrm{r}) \cdot \mathrm{d}^{3} \mathrm{r}}{\sqrt{\text { tumour }}}$ & $\mathrm{OF}_{4}=\frac{\int \operatorname{SAR}(\mathrm{r}) \cdot \mathrm{d}^{3} \mathrm{r}}{\sqrt{\int_{\text {tumour }}(\operatorname{SAR}(\mathrm{r}))^{2} \cdot \mathrm{d}^{3} \mathrm{r} \int_{\text {healthy }} \int \alpha(\mathrm{r})(\mathrm{SAR}(\mathrm{r}))^{2} \cdot \mathrm{d}^{3} \mathrm{r}}}$ \\
\hline $\mathrm{OF}_{5}=\frac{\int_{\text {tumour }} \operatorname{SAR}(\mathrm{r}) \mathrm{d}^{3} \mathrm{r}}{\sqrt{\int_{\text {healthy tissues }}\left(\frac{\mathrm{SAR}(\mathrm{r})}{\mathrm{W}(\mathrm{r})}\right)^{2} \cdot \mathrm{d}^{3} \mathrm{r}}}$ & $\mathrm{OF}_{6}=\frac{\int_{\text {tumour }} \operatorname{SAR}(\mathrm{r}) \cdot \mathrm{d}^{3} \mathrm{r}}{\sqrt{\int_{\text {tumour }}\left(\frac{\mathrm{SAR}(\mathrm{r})}{\mathrm{W}(\mathrm{r})}\right)^{2} \cdot \mathrm{d}^{3} \mathrm{r} \int_{\text {healthy tissues }} \alpha(\mathrm{r})\left(\frac{\mathrm{SAR}(\mathrm{r})}{\mathrm{W}(\mathrm{r})}\right)^{2} \cdot \mathrm{d}^{3} \mathrm{r}}}$ \\
\hline
\end{tabular}

each source having amplitude equal to one and phase equal to zero

$$
\overrightarrow{\mathrm{E}}(\overrightarrow{\mathrm{r}})=\sum_{\mathrm{v}}^{\mathrm{x}, \mathrm{y}, \mathrm{z}} \mathbf{E}_{\mathrm{v}}(\overrightarrow{\mathrm{r}}) \exp \left(\mathrm{j} \psi_{\mathrm{v}}(\overrightarrow{\mathrm{r}})\right) \overrightarrow{\mathrm{e}}_{\mathrm{v}}
$$

Any configuration of sources may then be calculated by using the principle of linearity (4) and the theorem of superposition (5). By using the GA, optimized values of amplitudes and phases may finally be obtained

$$
\begin{aligned}
& \overrightarrow{\mathrm{E}}(\mathrm{A}, \varphi, \overrightarrow{\mathrm{r}})=\mathrm{A} \exp (\mathrm{j} \varphi) \sum_{\mathrm{v}}^{\mathrm{x}, \mathrm{y}, \mathrm{z}} \mathrm{E}_{\mathrm{v}}(\overrightarrow{\mathrm{r}}) \exp \left(\mathrm{j} \psi_{\mathrm{v}}(\overrightarrow{\mathrm{r}})\right) \overrightarrow{\mathrm{e}}_{\mathrm{v}} \\
& \overrightarrow{\mathrm{E}}\left(\mathrm{A}_{1}, \ldots, \mathrm{A}_{\mathrm{n}}, \varphi_{1}, \ldots, \varphi_{n} ; \vec{r}\right) \\
& \quad=\sum_{\mathrm{v}}^{\mathrm{x}, \mathrm{y}, \mathrm{z}} \sum_{\mathrm{i}-1}^{\mathrm{n}} \mathrm{A}_{\mathrm{i}} \mathrm{E}_{\mathrm{v}, \mathrm{i}}(\overrightarrow{\mathrm{r}}) \exp \left(\mathrm{j} \psi_{\mathrm{v}, \mathrm{i}}(\overrightarrow{\mathrm{r}})+\mathrm{j} \varphi_{i}\right) \overrightarrow{\mathrm{e}}_{\mathrm{v}} .
\end{aligned}
$$

Several constraints are prescribed for an optimal treatment: the SAR in a tumor has to be close to $50 \mathrm{~W} / \mathrm{kg}$, and the total power absorbed by the patient has to be lower than $1250 \mathrm{~W}$ [8]. To reach therapeutic temperatures around $42{ }^{\circ} \mathrm{C}$, a power density of about $20-40 \mathrm{~W} / \mathrm{kg}$ at the target region is required [9]. The GA allows us to take into account these two constraints.

\section{Objective Functions}

Several OFs based on the calculated SAR have been tested and compared [10]. In Table $\mathrm{I}, \mathrm{OF}_{1}, \mathrm{OF}_{3}$, and $\mathrm{OF}_{5}$ are defined as the ratio between the SAR in the tumor and the SAR in healthy tissues. $\mathrm{OF}_{2}, \mathrm{OF}_{4}$, and $\mathrm{OF}_{6}$ are defined as the ratio between the SAR in the tumor and the SAR in all tissues including healthy tissues and tumor. The GA maximizes the result of these OF in order to obtain maximum SAR in cancerous tissues and the minimun in other tissues. The objective functions $\mathrm{OF}_{2}, \mathrm{OF}_{4}$, and $\mathrm{OF}_{6}$ implement the $\alpha$ coefficient, which allows us to take into account the cooling down of the patient with an external device: $\alpha$ is small in the case of a cooled down region and is equal to one in the opposite case. In $\mathrm{OF}_{3}$ and $\mathrm{OF}_{4}$, the denominator of the function is replaced by the square of the SAR. In $\mathrm{OF}_{5}$ (respectively, $\mathrm{OF}_{6}$ ) the denominator of the func-

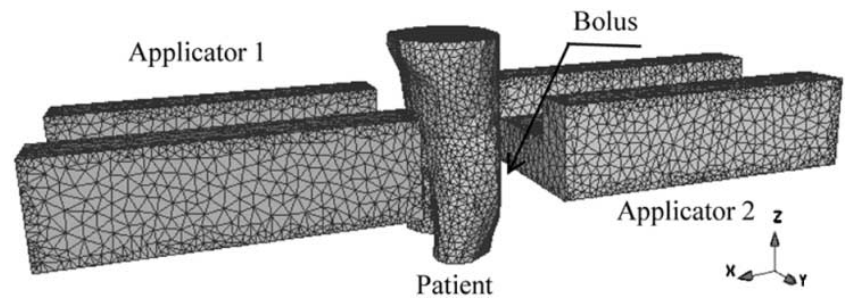

Fig. 1. Mesh of the waveguides applicator A1.

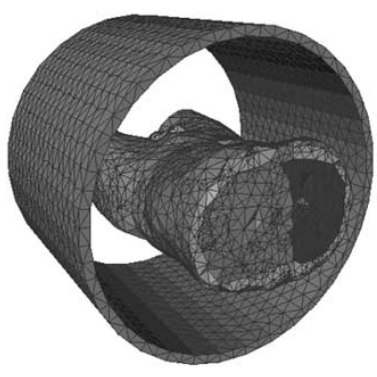

(a)

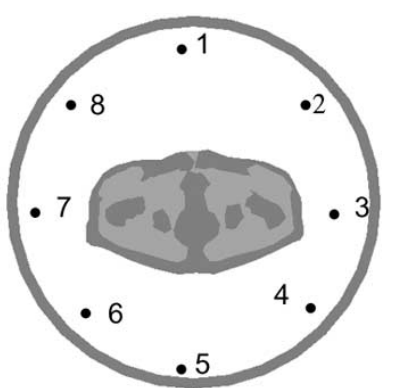

(b)
Fig. 2. APA applicator A2: (a) 3-D mesh and (b) location of the sources.

tion $\mathrm{OF}_{3}$ (respectively, $\mathrm{OF}_{4}$ ) is divided by $W$ (mass flow rate of blood per unit volume tissue) to consider the blood perfusion in each tissue.

\section{MODELED DEVICES}

Two types of hyperthermia systems are studied. The first one (A1) is made of two waveguides filled with conducting water and radiating at $27.12 \mathrm{MHz}$ (Fig. 1). The second applicator (A2) is an annular phased array (APA) made of a dielectric ring with eight 110-MHz sources (Fig. 2). For both devices, a pocket of water (bolus) fills the space around the patient in order to avoid excessive heating at the skin level. The patient model is created from 60 computerized tomography (CT) scans with a slice distance of $10 \mathrm{~mm}$. Table II summarizes the number of elements and degrees of freedom of both configurations.

The electromagnetic and thermal properties of the different biological tissues are presented in Table III. Electromagnetic 
TABLE II

MODELING OF THE HYPERTHERMIA SYSTEMS

\begin{tabular}{cccc}
\hline \hline Configuration & Tetrahedra & Nodes & Degrees of freedom \\
\hline A1 & 203989 & 42089 & 261500 \\
A2 & 146364 & 25879 & 174937 \\
\hline \hline
\end{tabular}

TABLE III

MATERIALS PROPERTIES FOR All SEGMENTEd TisSues (INCLUding THE TUMOR) USED IN THE PlanNing CALCUlations

\begin{tabular}{|c|c|c|c|c|c|c|}
\hline \multirow{2}{*}{ Tissues } & \multicolumn{2}{|c|}{$27.12 \mathrm{MHz}$} & \multicolumn{2}{|c|}{$110 \mathrm{MHz}$} & \multirow{2}{*}{$\begin{array}{c}\rho \\
\left(\mathrm{kg} / \mathrm{m}^{3}\right)\end{array}$} & \multirow{2}{*}{$\mathrm{W}\left(\mathrm{kg} / \mathrm{m}^{3} / \mathrm{s}\right.$} \\
\hline & $\varepsilon_{\mathrm{r}}$ & $\sigma(\mathrm{S} / \mathrm{m})$ & $\varepsilon_{\mathrm{r}}$ & $\sigma(\mathrm{s} / \mathrm{m})$ & & \\
\hline$\overline{\text { Fat }}$ & 8,4 & 0,033 & 6,0 & 0.036 & 900 & 0.477 \\
\hline Muscle & 95,8 & 0,65 & 64,9 & 0,712 & 1020 & 3.57 \\
\hline Bone & 21,8 & 0,05 & 15.1 & 0.065 & 1790 & 0.797 \\
\hline Kidney & 188 & 0,62 & 94,6 & 0.826 & 1050 & 67.7 \\
\hline Spleen & 188 & 0,64 & 87,4 & 0,814 & 1050 & 10.2 \\
\hline Blood & 127 & 1,16 & 75,3 & 1,24 & 1060 & 83.3 \\
\hline Liver & 120 & 0,38 & 67,1 & 0,496 & 1050 & 9.18 \\
\hline Bladder & 31,5 & 0,28 & 22,3 & 0,295 & 1060 & 9.99 \\
\hline Intestine & 202 & 1,48 & 93,0 & 1,67 & 1050 & 3.33 \\
\hline Tumour & 60 & 0,8 & 60 & 0.8 & 1177 & 0.624 \\
\hline \multicolumn{3}{|c|}{$\overline{\varepsilon_{\mathrm{r}} \text { real permittivity }}$} & \multicolumn{3}{|c|}{$\rho$ density $\left(\mathrm{kg} / \mathrm{m}^{3}\right)$} & $\left.\mathrm{m}^{3} / \mathrm{s}\right)$ \\
\hline
\end{tabular}

TABLE IV

OPTIMIZATION RESULTS FOR THE WAVEGUIDES APPLICATOR A1

\begin{tabular}{|c|c|c|c|c|c|c|c|c|}
\hline \multirow[t]{2}{*}{ Config. } & \multicolumn{2}{|c|}{ Source 1} & \multicolumn{2}{|c|}{ Source 2} & \multirow[t]{2}{*}{ OF } & \multirow{2}{*}{$\frac{P_{\text {patient }}}{W}$} & \multirow{2}{*}{$\frac{P_{\text {tumour }}}{W}$} & \multirow{2}{*}{$\frac{\mathrm{SAR}_{\text {tumeur }}}{\mathrm{W} / \mathrm{kg}}$} \\
\hline & $\mathrm{A}$ & $\varphi$ & $\mathrm{A}$ & $\varphi^{\circ}$ & & & & \\
\hline \multicolumn{9}{|l|}{ Default values } \\
\hline source $1 \mathrm{OF}_{1}$ & 1 & 0 & - & - & 1.30 & 213 & 1.6 & 7.5 \\
\hline source $2 \mathrm{OF}_{1}$ & - & - & 1 & 0 & 1.75 & 133 & 1.2 & 5.6 \\
\hline $\mathrm{OF}_{1}$ & 1 & 0 & 1 & 0 & 1.52 & 484 & 4.3 & 19.9 \\
\hline $\mathrm{OF}_{2}(\alpha=0.5)$ & 1 & 0 & 1 & 0 & 2.53 & 484 & 4.3 & 19.9 \\
\hline $\mathrm{OF}_{3}$ & 1 & 0 & 1 & 0 & 2.91 & 484 & 4.3 & 19.9 \\
\hline $\mathrm{OF}_{4}(\alpha=1)$ & 1 & 0 & 1 & 0 & 3.07 & 484 & 4.3 & 19.9 \\
\hline $\mathrm{OF}_{5}$ & 1 & 0 & 1 & 0 & 7.10 & 484 & 4.3 & 19.9 \\
\hline $\mathrm{OF}_{6}(\alpha=1)$ & 1 & 0 & 1 & 0 & 4.89 & 484 & 4.3 & 19.9 \\
\hline \multicolumn{9}{|l|}{ Optimal values } \\
\hline $\mathrm{OF}_{1}$ & 1.15 & 0 & 2.63 & 235 & 2.30 & 824 & 8.9 & 41.2 \\
\hline $\mathrm{OF}_{2}(\alpha=0.5)$ & 1.15 & 0 & 2.63 & 235 & 3.38 & 825 & 8.9 & 41.2 \\
\hline $\mathrm{OF}_{3}$ & 1.24 & 0 & 2.62 & 233 & 4.40 & 830 & 8.9 & 41.0 \\
\hline $\mathrm{OF}_{4}(\alpha=1)$ & 1.33 & 0 & 2.82 & 233 & 3.95 & 995 & 10.2 & 47.2 \\
\hline $\mathrm{OF}_{5}$ & 1.12 & 0 & 2.57 & 243 & 9.57 & 1030 & 9.1 & 42.0 \\
\hline $\mathrm{OF}_{6}(\alpha=1)$ & 1.19 & 0 & 2.73 & 243 & 5.38 & 929 & 10.2 & 46.9 \\
\hline
\end{tabular}

characteristics are obtained from the Gabriel library [11] and thermal properties (mass flow rate) are given in [12].

\section{OPTIMIZATION RESULTS}

\section{A. Applicator Al}

The results of the optimization for applicator A1 are presented in Table IV. Different configurations are compared, with only one source operating (source 1, source 2), with both waveguides operating simultaneously with default adjustments (default values). A and $\varphi$ denote, respectively, amplitude and phase of sources. The optimal configurations obtained with the GA for the several OFs are presented. The SAR distribution on bone and tumor is shown in Fig. 3 for default (a) and optimal (b) configurations in the case of function $\mathrm{OF}_{1}$. Fig. 4 gives the ratio between SAR in healthy tissues and in the tumor.

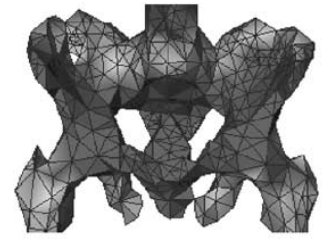

(a)

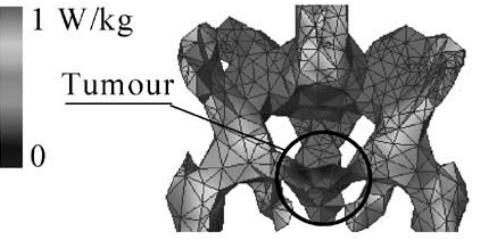

(b)
Fig. 3. SAR distribution on bone and tumor for (a) the default and (b) optimized configurations with the $\mathrm{OF}_{1}$ function.

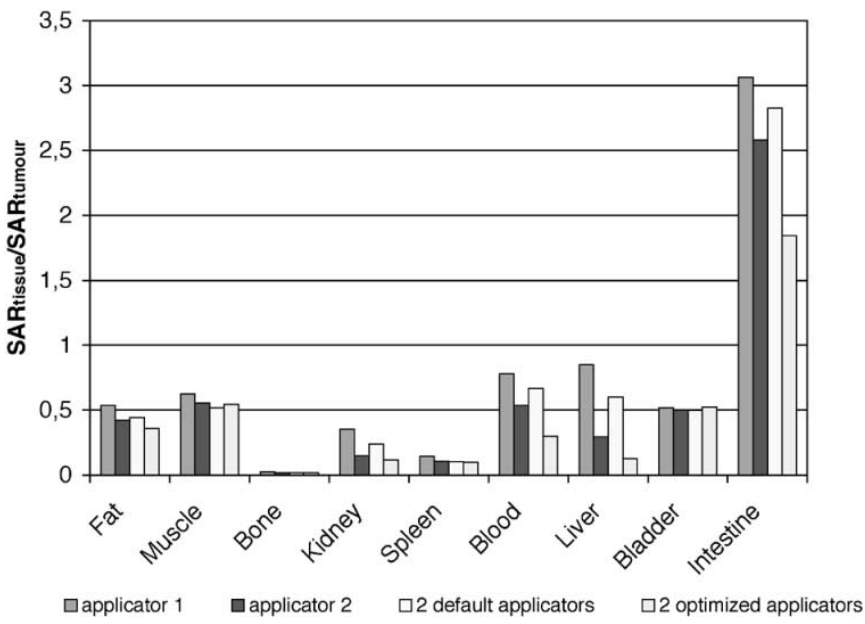

Fig. 4. SAR ratio between the different biological tissues and tumoral tissue for the waveguide configuration (A1) with $\mathrm{OF}_{1}$ function.

TABLE V

OPTIMIZATION RESULTS FOR THE APA APPLICATOR A2

\begin{tabular}{lcccc}
\hline \hline Configuration & OF & $\begin{array}{c}\mathrm{P}_{\text {patient }} \\
\mathrm{W}\end{array}$ & $\begin{array}{c}\mathrm{P}_{\text {tumour }} \\
\mathrm{W}\end{array}$ & $\begin{array}{c}\mathrm{SAR}_{\text {tumeur }} \\
\mathrm{W} / \mathrm{kg}\end{array}$ \\
\hline Default values & & & & \\
$\mathrm{OF}_{1}$ (source 1 alone) & 0.286 & 2.4 & 0.04 & 0.20 \\
$\mathrm{OF}_{1}$ & 1.20 & 53.7 & 0.82 & 3.50 \\
$\mathrm{OF}_{2} \alpha=1$ & 1.18 & 53.7 & 0.82 & 3.30 \\
$\mathrm{OF}_{2} \alpha=0.5$ & 2.11 & 53.7 & 0.82 & 3.30 \\
$\mathrm{OF}_{3}$ & 0.78 & 53.7 & 0.82 & 3.30 \\
$\mathrm{OF}_{4}$ & 0.79 & 53.7 & 0.82 & 3.30 \\
$\mathrm{OF}_{5}$ & 14.9 & 53.7 & 0.82 & 3.30 \\
$\mathrm{OF}_{6}$ & 0.58 & 53.7 & 0.82 & 3.30 \\
\hline $\mathrm{Optimal} \mathrm{values}_{\mathrm{OF}_{1}}$ & & & \\
$\mathrm{OF}_{2} \alpha=1$ & 5.80 & 221 & 14.9 & 69.0 \\
$\mathrm{OF}_{2} \alpha=0.5$ & 3.83 & 128 & 8.78 & 40.5 \\
$\mathrm{OF}_{3}$ & 5.64 & 187 & 12.8 & 59.3 \\
$\mathrm{OF}_{4}$ & 10.96 & 187 & 12.6 & 58.1 \\
$\mathrm{OF}_{5}$ & 7.54 & 169 & 11.5 & 53.3 \\
$\mathrm{OF}_{6}$ & 77.3 & 147 & 10.54 & 48.6 \\
\hline
\end{tabular}

\section{B. Applicator A2}

Results of optimization for applicator A2 are given in Table V. Optimal results obtained with objective function $\mathrm{OF}_{1}$ are compared to those obtained with only one source and to those obtained with all sources in phase. Fig. 5 shows the SAR ratio between SAR in healthy tissues and in the tumor for the APA configuration (A2). Computations are performed on an HP station J5000. CPU times for this applicator are given in Table VI. The assembling of the FE matrix is performed only once and is included in the computation of the source 1 . Note that the number of iterations of the GA is small, leading to optimization time largely lower than computation time. 


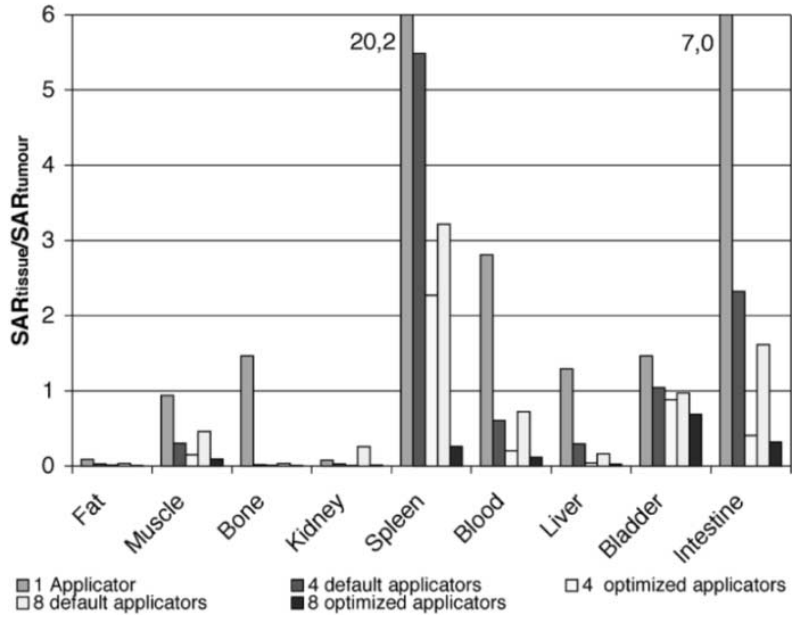

Fig. 5. SAR ratio between tissues and tumor for the APA configuration (A2).

TABLE VI

COMPUTATION AND OPTIMIZATION TIMES FOR THE APA APPLICATOR A2

\begin{tabular}{llc}
\hline \hline & & CPU times (sec) \\
\hline E field calculation & Source 1 & 8854 \\
& Source 2 to 8 & $7 \times 4047$ \\
Optimization & & 1208 \\
Total & & 38391 \\
\hline \hline
\end{tabular}

\section{Comments}

Obviously, the optimization procedure allows us to increase the SAR in the tumor and to decrease it in healthy tissues with several constraints linked to hyperthermia therapeutic levels. It is difficult to get really significant conclusions on the best objective function. With the A1 applicator, maximal value of the power density inside the tumor is obtained with OF4 and OF6. On the other hand, for applicator A2, it is obtained with OF1 and then OF3 and OF6. On the other hand, only the OF5 and OF6 allow us to consider the blood perfusion of the tissues which may have a great role in hypertermia treatment. Furthermore, the OF6 function leads to lower CPU times for the optimization process (Table VII). From all of these elements, it seems that a good compromise could be the OF6.

\section{CONCLUSION}

A 3-D optimization tool based on a coupled GA-FE method has been developed for hyperthermia treatment. It allows us to obtain the best settings of sources leading to a better focalization
TABLE VII

GLOBAL CPU TIMES FOR OPTIMIZATION WITH THE APA APPLICATOR A2

\begin{tabular}{lcccc}
\hline \multicolumn{1}{c}{ OF } & \multicolumn{2}{c}{ A1 } & \multicolumn{2}{c}{$\mathrm{A} 2$} \\
\hline $\mathrm{OF}_{1}$ & Generations & CPU Times & Generations & CPU Times \\
$\mathrm{OF}_{2} \alpha=1$ & 27 & 303 & 48 & 1233 \\
$\mathrm{OF}_{2} \alpha=0.5$ & 16 & 178 & 51 & 1260 \\
$\mathrm{OF}_{3}$ & 34 & 378 & 47 & 1159 \\
$\mathrm{OF}_{4}$ & 22 & 262 & 70 & 1714 \\
$\mathrm{OF}_{5}$ & 41 & 462 & 25 & 599 \\
$\mathrm{OF}_{6}$ & 35 & 385 & 65 & 1569 \\
\hline \hline
\end{tabular}

of the SAR into the tumor. The next step of this work is oriented toward the calculation of the temperature distribution resulting from the optimal SAR distribution.

\section{REFERENCES}

[1] O. S. Nielsen, M. Horsman, and J. Overgaard, "A future for hyperthermia in cancer treatment," Eur. J. Cancer, vol. 37, pp. 1587-1589, 2001.

[2] B. Hildebrandt, P. Wust, O. Ahlers, A. Dieing, G. Sreenivasa, T. Kerner, R. Felix, and H. Riess, "The cellular and molecular basis of hyperthermia," Crit. Rev. Oncology/Hematology, vol. 43, pp. 33-56, 2002.

[3] C. Niderst, Ph.D. dissertation, Université Paul Sabatier, Toulouse, France, 1997.

[4] B. Sareni, L. Krähenbühl, and A. Nicolas, "Niching genetic algorithms for optimization in electromagnetics-I. Fundamentals," IEEE Trans. Magn., vol. 34, pp. 2984-2987, Sept. 1998.

[5] N. Siauve, L. Nicolas, C. Vollaire, and C. Marchal, "3D modeling of electromagnetic fields in local hyperthermia," Eur. Phys. J. AP, vol. 21, pp. 243-250, 2003.

[6] A. Bossavit and I. Mayergoyz, "Edge-elements for scattering problems," IEEE Trans. Magn., vol. 25, pp. 2816-2821, July 1989.

[7] R. Perrussel, L. Nicolas, and F. Musy, "An efficient preconditioner for linear systems issued from the finite element method for scattering problems," in Proc. COMPUMAG 2003, 14th Conf. Computation Electromagnetic Fields, Saratoga Springs, NY.

[8] P. Wust, M. Seebass, J. Nadobny, P. Deuflhard, G. Monich, and R. Felix, "Simulation studies promote technological development of radiofrequency phased array hyperthermia," Int. J. Hyperthermia, vol. 12, pp. 477-494, 1996.

[9] P. Wust, B. Hiledebrandt, G. Sreenivasa, B. Rau, J. Gellerman, H. Riess, R. Felix, and P. M. Dchlag, "Hyperthermia in combined treatment cancer," Lancet Oncology, vol. 3, pp. 487-497, 2002.

[10] J. Wiersma, R. A. M. Van Maarseveen, and J. D. P. Van Dijk, "A flexible optimization tool for hyperthermia treatments with RF phased array systems," Int. J. Hyperthermia, vol. 18, no. 2, pp. 73-85, 2002.

[11] S. Gabriel, R. W. Lau, and C. Gabriel, "The dielectric properties of biological tissues: III. Parametric models for the dielectric spectrum of tissues," Phys. Med. Biol., vol. 41, pp. 2271-2293, 1996.

[12] P. Van den Berg, A. T. De Hoop, A. Segal, and N. Praagman, "A computational model of the electromagnetic heating of biological tissue with application to hyperthermic cancer therapy," IEEE Trans. Biomed. Eng., vol. 30, pp. 797-805, 1983. 